Article

\title{
Yield Component Responses of the Brachiaria brizantha Forage Grass to Soil Water Availability in the Brazilian Cerrado
}

\author{
Camila Thaiana Rueda da Silva ${ }^{1}$, Edna Maria Bonfim-Silva ${ }^{1, * \mathbb{C}}$, Tonny José de Araújo da Silva ${ }^{1}$, \\ Everton Alves Rodrigues Pinheiro ${ }^{1}$, Jefferson Vieira José ${ }^{2}$ and André Pereira Freire Ferraz ${ }^{1}$ (D) \\ 1 Institute of Agricultural and Technological Sciences, Federal University of Mato Grosso, \\ Rondonópolis, MT 78735-901, Brazil; camilarueda13@gmail.com (C.T.R.d.S.); \\ tonnyjasilva@hotmail.com (T.J.d.A.d.S.); pinheiroear@gmail.com (E.A.R.P.); \\ andrepfferraz@gmail.com (A.P.F.F.) \\ 2 Multidisciplinary Center, Federal University of Acre, Cruzeiro do Sul, AC 69895-000, Brazil; \\ jfvieira@hotmail.com.br \\ * Correspondence: embonfim@hotmail.com
}

Received: 6 December 2019; Accepted: 1 January 2020; Published: 5 January 2020

\begin{abstract}
Brazil is one of the world's largest producers of beef cattle and dairy products, which requires high forage yield to attend grass-fed animals' demand. Among the grass species adopted in the forage production system in Brazil, the Brachiaria genus stands out. This genus comprises nearly $85 \%$ of all planted forage area. In general, forage production systems in Brazil are essentially rainfed, and thus susceptible to seasonal soil water stresses. Selecting the suitable Brachiaria cultivar for lands susceptible to periodic waterlogging and dry spells is crucial to enhance forage yield, and consequently, to reduce the environmental footprint of the livestock sector. In this research, we investigated the performance of three recent commercial Brachiaria brizantha cultivars (Piatã, BRS Paiaguás, and MG13 Braúna) extensively adopted in Brazil's grazing systems subjected to different ranges of soil water potential. For three cutting periods, yield related-variables (e.g., plant height, leaf area, dry biomass, and water use efficiency) were measured. Our results point to the existence of a low drought-resistant trait among cultivars, indicating the need for releasing better-adapted cultivars to cope with reduced soil water availability. All cultivars achieved higher performance at soil water pressure head between $-15 \mathrm{kPa}$ and $-25 \mathrm{kPa}$; and in general, the cultivar. Piatã showed slightly superior results to most of the treatments.
\end{abstract}

Keywords: beef cattle; dehydration response; tropical forages

\section{Introduction}

Cattle ranching is one of the largest agricultural activities in Brazil [1]; where around 90\% of the cattle herds are pasture-fed [2]. Both natural and planted pasture lands occupy roughly $200 \mathrm{Mha}$, primarily used to feed beef cattle [3]. In this system, the forage production is essentially rainfed, in which over $80 \%$ of the yield occurs during the rainy season, thus the forage production is highly susceptible to seasonal water stress due to either waterlogging or drought [4-6]. Sustainable pasture management is a key element in the enhancement of productivity and reduction of the conversion of natural forests into grasslands, and consequently, the decrease of the environmental footprint of the livestock sector [7]. Although most of the improvements are driven towards the development of new inputs (e.g., seeds, fertilizers, and machinery adoption), the selection of adequate forage cultivars based on their water demand according to the local water availability patterns seems a safe path to improve productivity and manage water consumption by grasslands. 
In order to sustain the Brazilian cattle ranching activity growth expected for this decade $[3,8]$, planted grassland currently corresponds to nearly $120 \mathrm{Mha}$ (60\% of the total area). It is worth noting that $85 \%$ of these planted pasture lands are comprised of Brachiaria spp., a tropical forage grass that has been largely used by the Brazilian cattle ranchers since the 1950s [2,9]. In general, the Brachiaria genus is distributed throughout the entire tropical zone, showing high biomass yield potential for both grazing and ensiling [10-12].

Regarding the Cerrado biome (Brazilian savannah), the last agricultural frontier of the country, 60 Mha is used as grazing land, with 51 Mha cropped with Brachiaria genus [6,13]. In general, for this large producer region of beef and dairy products, there is limited information on selecting the suitable Brachiaria cultivar for lands susceptible to periodic waterlogging and dry spells. Thus, in order to allow correct cultivar selection, it is necessary to know the yield response of the regional forage cultivars to the natural conditions of water stress. In this study, we investigated the performance of three important commercial B. brizantha cultivars extensively adopted in grazing systems in the Cerrado region subjected to different ranges of soil water potential (from complete saturation to moderate drought). Given the varied range of habitats in which this grass forage grows, we hypothesized that under similar conditions of water stress, some cultivars may outperform their counterparts in terms of plant growth variables, and consequently biomass yield. The experiment was carried out in a greenhouse to allow controlled water management and the measurement of phenotypic variables related to grass biomass yield. The general aim of our research is to generate information to support future field experiments under larger ranges of soil water availability, and thus, to assist cattle ranchers in the selection of the best $B$. brizantha cultivars for the establishment of grazing systems.

\section{Materials and Methods}

The Brazilian Research Agricultural Corporation (EMBRAPA) released the Brachiaria brizantha cultivars Piatã and BRS Paiaguás, while the Matsuda Group launched the cultivar MG13 Braúna. These cultivars are largely adopted in grazing fields in the Brazilian Cerrado due to their recognized nutritional value, and their claimed biomass yield during dry seasons. The general adaptation characteristics and yield patterns of these cultivars obey the rule of increasing pasture and animal productivity. These features are based on the well-documented biomass yield and pasture quality achieved by the Brachiaria genus in tropical savannahs $[2,5,14,15]$.

\subsection{Experimental Design and General Soil Properties}

A greenhouse experiment was conducted at the Federal University of Mato Grosso campus in Rondonópolis, Brazil ( $16^{\circ} 28^{\prime} \mathrm{S}, 50^{\circ} 34^{\prime} \mathrm{W} ; 248 \mathrm{~m}$ above sea level). The Köppen climate type is Aw-tropical zone with dry winter [16]. Throughout the experiment, the greenhouse presented an average relative humidity and air temperature of $61 \%$ and $26.4{ }^{\circ} \mathrm{C}$, respectively.

For the purpose of this research, we selected a coarse-textured soil classified as Fluvisol according to the IUSS Working Group WRB [17], which is prone to waterlogging during the rainy season and drought during the dry season. This soil group occupies large areas in the Cerrado biome and is usually located at and nearby river flood plains. Consequently, this soil group is generally used for forage production (grazing) due to the risks related to yield failures that it offers to cash crops (e.g., soybean, maize, and cotton), which are more resource-demanding.

Disturbed soil samples were collected from the top soil layer $(0-0.2 \mathrm{~m})$, and then passed through a $4 \mathrm{~mm}$ sieve for the composition of the experimental units. Additional soil samples passed through a $2 \mathrm{~mm}$ sieve for natural chemical status and particle-size distribution analysis, Table 1. 
Table 1. Soil chemical and particle size distribution analysis for the sampled soil.

\begin{tabular}{|c|c|c|c|c|c|c|c|c|c|c|c|}
\hline $\mathrm{pH} \mathrm{CaCl}_{2}$ & $\mathbf{P}$ & $\mathbf{K}$ & $S$ & $\mathrm{Ca}$ & Mg & Al & $\mathbf{H}+\mathbf{A l}$ & C.E.C. & O.M. & $\mathbf{V}$ & $\mathbf{m}$ \\
\hline & \multicolumn{3}{|c|}{$\mathrm{mg} \cdot \mathrm{dm}^{-3}$} & \multicolumn{4}{|c|}{$\mathrm{cmol}_{\mathrm{c}} \cdot \mathrm{dm}^{-3}$} & & $\mathrm{~g} \cdot \mathrm{kg}^{-1}$ & \multicolumn{2}{|c|}{$\%$} \\
\hline 5.3 & 20.4 & 47 & 2 & 4.3 & 0.8 & 0.0 & 2.7 & 7.9 & 21.0 & 65.9 & 0.0 \\
\hline $\mathrm{Zn}$ & Mn & & $\mathrm{Cu}$ & & & $\mathrm{Fe}$ & & B & Clay & Silt & Sand \\
\hline \multicolumn{9}{|c|}{$\mathrm{mg} \cdot \mathrm{dm}^{-3}$} & \multicolumn{3}{|c|}{$\mathrm{g} \cdot \mathrm{kg}^{-1}$} \\
\hline 10.5 & 68.0 & & 0.8 & & & 93 & & 0.13 & 145 & 150 & 705 \\
\hline
\end{tabular}

$\mathrm{P}=$ phosphorus, $\mathrm{K}=$ potassium, $\mathrm{S}=$ sulfur, $\mathrm{Ca}=$ calcium, $\mathrm{Mg}=$ magnesium, $\mathrm{Al}=$ aluminum, $\mathrm{C} . \mathrm{E} . \mathrm{C}=$ cation exchange capacity, O.M. = organic matter, $\mathrm{V}=$ base saturation, $\mathrm{m}=$ aluminum saturation, $\mathrm{Zn}=$ zinc, $\mathrm{Mn}=$ manganese, $\mathrm{Cu}=$ copper, $\mathrm{Fe}=$ iron, and $\mathrm{B}=$ boron.

Nitrogen, phosphorus, and potassium were supplied according to the demand required by the Brachiaria spp. The following nutrient doses were applied for all plants: $200 \mathrm{mg} \cdot \mathrm{dm}^{-3}$ of nitrogen, $150 \mathrm{mg} \cdot \mathrm{dm}^{-3}$ of phosphorus applied in unique dose at sowing, and $100 \mathrm{mg} \cdot \mathrm{dm}^{-3}$ of potassium. The used mineral sources were urea, single superphosphate, and potassium chloride, respectively. The sieved soil and the single superphosphate were mixed together, and this homogenized material was used to fill 72 pots of $5 \mathrm{~L}$ each ( $5 \mathrm{~kg}$ of soil material for each pot). The potassium chloride and urea were diluted in water and applied at the beginning of the experiment and as restitution minerals throughout the crop cycles (growth and regrowth) for all treatments. A randomized block design (with four replicates) was used for this experiment, adopting a factorial scheme $3 \times 6$ (three Brachiaria cultivars: MG13 Braúna, BRS Paiaguás, and Piatã; and six values of soil water pressure heads: $0,-10$, $-20,-30,-40$, and $-50 \mathrm{kPa}$ ), totaling 72 pots, where each pot was considered as an experimental unit.

The soil water retention curve $h(\theta)$, the analytical relationship between soil water content $(\theta)$ and the soil water pressure head $(h)$, were obtained using a different set of pots with similar volumetric capacity. Water-filled tensiometers were installed in those pots (four replicas) with previously saturated soil. The soil water content was monitored by recording the weight change over time while the soil water pressure head was measured twice a day. The gravimetric water content was then converted to volumetric unit using the relation between bulk soil density and water density. The lowest value of pressure head recorded by the tensiometers was $-61 \mathrm{kPa}$, therefore, the soil water retention curve ranged from soil saturation to this lower bound of $-61 \mathrm{kPa}$. The soil water retention curve was described by the analytical $\theta-h$ function defined by [18], Equation (1), which was fitted to the obtained data-pairs $(\theta-h)$ minimizing the sum of squared errors using the RETC software [19]:

$$
\Theta=\left[1+|a h|^{n}\right]^{(1 / n)-1}
$$

where $\Theta=\left(\theta-\theta_{r}\right) /\left(\theta_{s}-\theta_{r}\right)$ is the effective saturation, $\theta\left(\mathrm{m}^{3} \mathrm{~m}^{-3}\right)$ is the water content, $h(\mathrm{kPa})$ is the pressure head, $\theta_{r}$ is the residual water content, $\theta_{s}$ is the saturated water content, and $\alpha\left(\mathrm{kPa}^{-1}\right)$, and $n$ are shape parameters. Figure 1 shows the fitted soil water retention curve of the soil material after accommodation in the pots. The high values of parameters $\alpha$ and $n$ confirm the expected hydraulic characteristic for a coarse-textured soil. It also shows that under the lowest applied pressure head during the experiment $(-50 \mathrm{kPa})$ the used soil material still holds water content over $20 \%$. 


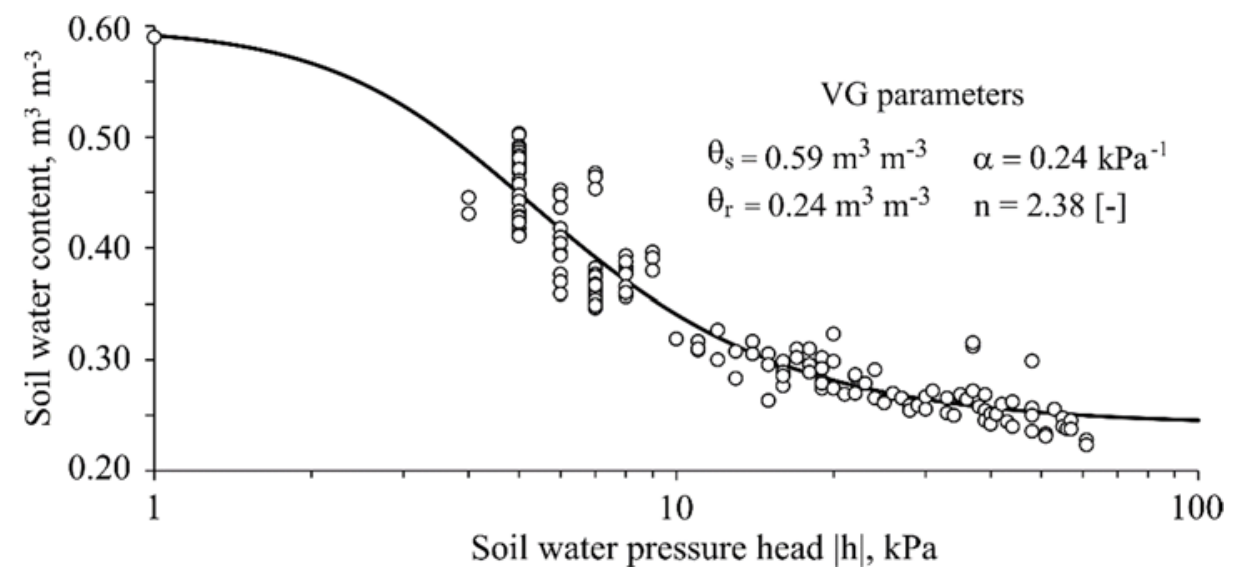

Figure 1. Soil water retention curve according to the Van Genuchten (VG) model [18] of the soil material after accommodation in the experimental units, together with its respective fitted parameters of Equation (1).

\subsection{Cultivars Sowing and Plant Establishment}

Approximately 50 seeds were sowed in each experimental unit (pot); four days after emergence (DAE), the seedlings were thinned out, leaving five vigorous plants in each experimental unit. At the 10th DAE, when plants were uniform and around $10 \mathrm{~cm}$ height, the soil water pressure head treatments were applied $(0,-10,-20,-30,-40$, and $-50 \mathrm{kPa})$. The pressure head measurements were recorded twice a day (early in the morning and by the end of the afternoon) during the entire experimental period (90 day); after the readings, the water inside the tensiometer tubes was replenished. A thin $1 \mathrm{~cm}$ water depth over the soil surface simulated the flooded condition treatment throughout the experiment, whereas the negative $h$ values simulated the moderate dehydration stress.

\subsection{Response Variables}

Thirty days after starting the treatments (40 DAE), plants were clipped at $5 \mathrm{~cm}$ above pot surface level to stimulate regrowth; this protocol was repeated twice throughout the experiment with the same time interval between cuts (30 day), totaling 90 days of experiment. At each cut, the following variables were measured: plant height $(\mathrm{cm})$; leaf area $\left(\mathrm{cm}^{2} \cdot\right.$ pot $\left.^{-1}\right)$; actual bulk leaf succulence $\left(\mathrm{g} \cdot \mathrm{cm}^{-2}\right.$; for the first and third cuts); aboveground dry biomass $\left(\mathrm{g} \cdot \mathrm{pot}^{-1}\right)$; water use efficiency $\left(\mathrm{kg} \cdot \mathrm{m}^{-3}\right.$; for the second cut); and root dry biomass (g.pot ${ }^{-1}$, measured only once at the end of the experiment).

Plant height was considered as the vertical distance from the pot soil surface to the curvature point of the last expanded leaf. The leaf area $(L A)$ measurements were performed using a LI 3100 area meter (LI-COR Bio-Science). Regarding the dry biomass measurements, the fresh material was packed in proper paper bags and allowed to dry in a forced-air ventilation oven at $65^{\circ} \mathrm{C}$.

The following relation was used to obtain the actual bulk leaf succulence $\left(L S, \mathrm{~g} \cdot \mathrm{cm}^{-2}\right)$, an indicative of pasture palatability:

$$
\mathrm{LS}=\frac{F L B-D L B}{L A}
$$

where FLB is the fresh harvested leaves, and DLB is the dry leaf biomass.

The agricultural water use efficiency (WUE) is the ratio between the amount (e.g., biomass) of agricultural yield per a volume (or value) of water used for achieving this production. The most common units for expressing water use efficiency are $\mathrm{kg} \cdot \mathrm{m}^{-3}$ or ton $\cdot \mathrm{m}^{-3}$, i.e., the mass of agricultural yield per volume of water used [20,21]. Expressing WUE in $\mathrm{kg} \cdot \mathrm{m}^{-3}$, we calculated it by the ratio between aboveground dry biomass yield $(\mathrm{kg})$ of each pot (PY) and the amount of water consumed by the crop (ET) during the growth period:

$$
\mathrm{WUE}=\frac{P Y}{E T}
$$


With controlled water depth applied on pots with sealed bottom, no runoff or deep percolation occurred, and water use was strictly due to evaporation and transpiration processes. Thus, the daily water volume applied in each pot in order to maintain the pressure head values constant for each treatment throughout the experiment, was assumed as a proxy of evapotranspiration (ET) rate.

\subsection{Statistical Analysis}

The response variables were analyzed by one-way ANOVA to explore significant differences $(p<0.05)$ among the three Brachiaria brizantha cultivars subjected to the water pressure head treatments. In case of significant interaction between the evaluated factors (cultivars and soil water pressure heads), the respective response variable was subjected to regression analysis for each cultivar as a function of the quantitative factor (soil water pressure head) at $p<0.05$.

\section{Results and Discussion}

\subsection{Plant Height}

Both sources of variation (cultivars and soil water pressure heads- $h$ ) affected plant height. However, interaction effect between $h$ treatments and plant height was observed only for the second cut (Table 2 and Figure 2). The cultivar Piatã obtained the highest values for the three cuts at all $h$ values, followed by the BRS Paiaguás for the first and third cuts, while for the second cut, the cultivar MG13 Braúna outperformed the BRS Paiaguás at $h$ values $-30 \mathrm{kPa}$ and $-40 \mathrm{kPa}$.

Table 2. Effect of soil water pressure head on plant height (Brachiaria brizantha cultivars) for the three cutting periods.

\begin{tabular}{|c|c|c|c|c|c|c|}
\hline & \multicolumn{6}{|c|}{ Plant Height ${ }^{1}(\mathrm{~cm})$} \\
\hline Cultivar & \multicolumn{6}{|c|}{ First Cut (40 day after emergence (DAE)) } \\
\hline Braúna & \multicolumn{6}{|c|}{$46.1 \mathrm{c} \pm 8.1$} \\
\hline Paiaguás & \multicolumn{6}{|c|}{$53.0 \mathrm{~b} \pm 10.7$} \\
\hline Piatã & \multicolumn{6}{|c|}{$61.0 \mathrm{a} \pm 10.1$} \\
\hline \multirow{3}{*}{ Cultivar } & \multicolumn{6}{|c|}{ Second cut (70 DAE) } \\
\hline & \multicolumn{6}{|c|}{ Soil water pressure head $(\mathrm{kPa})$} \\
\hline & 0 & -10 & -20 & -30 & -40 & -50 \\
\hline Braúna & $49.8 b \pm 6.3$ & $68.9 b \pm 2.9$ & $69.0 \mathrm{~b} \pm 3.0$ & $66.3 b \pm 5.7$ & $59.0 \mathrm{a} \pm 5.5$ & $39.2 \mathrm{a} \pm 5.6$ \\
\hline Paiaguás & $59.2 b \pm 5.0$ & $82.0 \mathrm{a} \pm 6.6$ & $78.6 \mathrm{ab} \pm 7.0$ & $59.2 b \pm 10.8$ & $56.9 \mathrm{a} \pm 5.7$ & $40.6 \mathrm{a} \pm 8.7$ \\
\hline Piatã & $78.4 \mathrm{a} \pm 7.8$ & $92.8 \mathrm{a} \pm 4.3$ & $84.0 \mathrm{a} \pm 10.0$ & $86.2 \mathrm{a} \pm 5.6$ & $67.9 \mathrm{a} \pm 9.2$ & $48.6 \mathrm{a} \pm 6.7$ \\
\hline Cultivar & \multicolumn{6}{|c|}{ Third cut (100 DAE) } \\
\hline Braúna & \multicolumn{6}{|c|}{$46.9 \mathrm{c} \pm 14.0$} \\
\hline Paiaguás & \multicolumn{6}{|c|}{$48.1 \mathrm{~b} \pm 16.2$} \\
\hline Piatã & \multicolumn{6}{|c|}{$54.6 \mathrm{a} \pm 16.8$} \\
\hline
\end{tabular}

(pressure head) and cuts do not differ from each other statistically according to the Tukey's test at $p<0.05$.

Figure 2 shows the quadratic-shaped regression models fitted between soil water pressure head and plant height data for all evaluated scenarios. In general, the highest values were observed for $h$ ranging from $-10 \mathrm{kPa}$ to $-20 \mathrm{kPa}$. Comparing the observed plant heights in this optimum $h$ range to those from wetter and drier soil conditions, reductions of up to $36 \%$ and $60 \%$ occurred, respectively, indicating that plant height of the studied B. brizantha cultivars is susceptible to both waterlogging and moderate dehydration stress, though dehydration stress seems to be a more severe constraint. Some research indicates that height alteration of plants exposed to waterlogging stress may be related to morphological plant responses to reduced soil air-filled porosity [22], which may trigger stem elongation as an attempt to increase access to, and diffusion of, $\mathrm{O}_{2}$ [23]. 

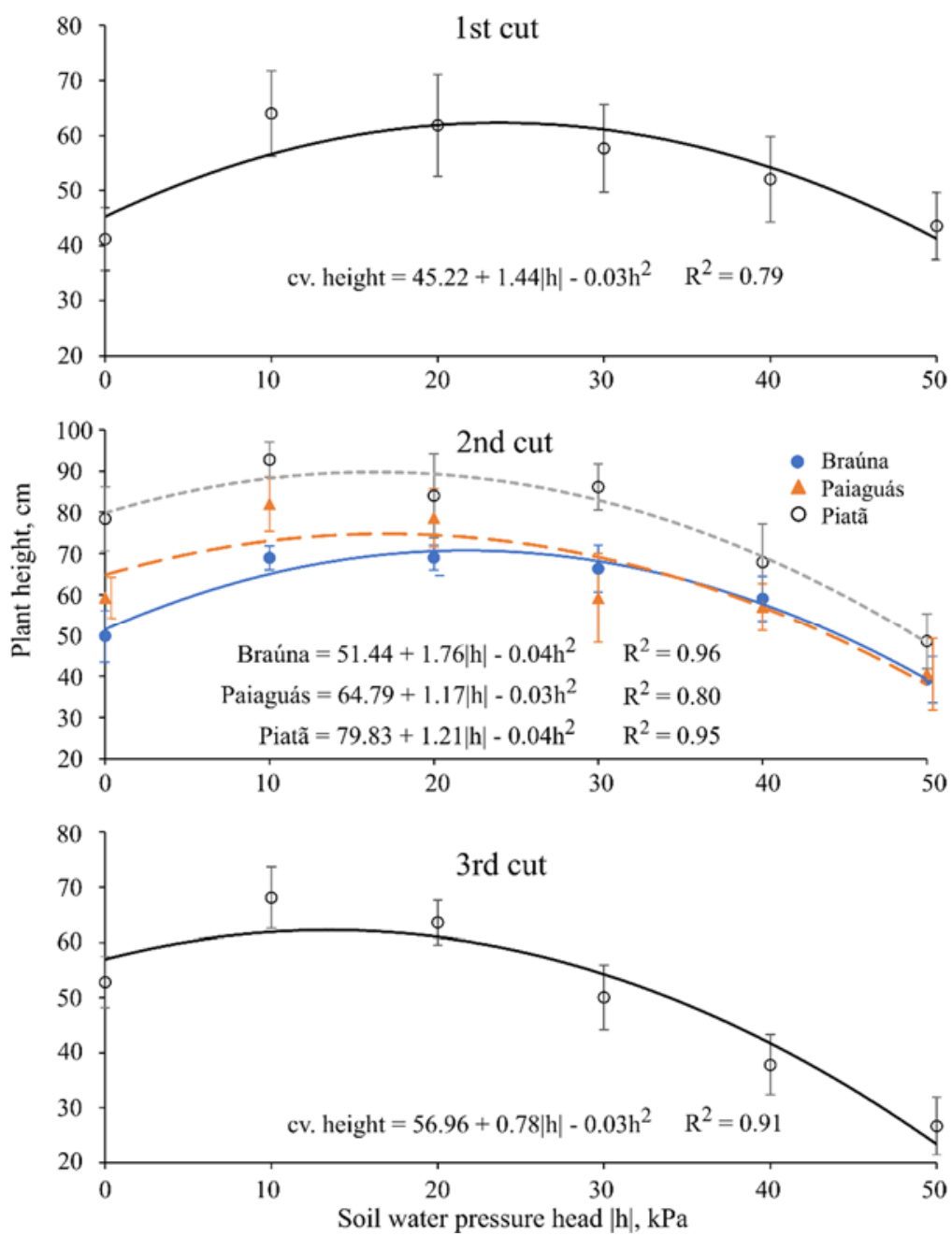

Figure 2. Regression models relating soil water pressure head to plant height of Brachiaria brizantha cultivars for the three cutting periods (40,70, and 100 DAE (days after emergence)). Error bars correspond to the standard deviation of the four replicas.

\subsection{Leaf Area}

The applied pressure head treatments significantly affected $(p<0.05)$ the leaf area $(L A)$ at the first and second cuts (Table 3 and Figure 3). For the first cut, at and near soil saturation, the cultivars BRS Paiaguás and Piatã obtained the highest $L A$ values. For drier soil conditions $(h=-40$ and $h=-50 \mathrm{kPa})$ the observed numerical differences among cultivars were not statistically significant. Regarding the second cut, at soil saturation the cultivar Piatã obtained the highest $L A$ value, whereas at $-30 \mathrm{kPa}$ the cultivar BRS Paiaguás obtained the lowest $L A$. For all other pressure head values, the differences were not significant $(p>0.05)$.

According to Figure 3, the optimum soil pressure head range for leaf area development was from -15 to $-25 \mathrm{kPa}$. Regarding the first cut, similar $L A$ reduction was observed for both stresses (water excess and moderate dehydration). On the other hand, for the second and third cuts the dehydration stress was more limiting to $L A$ than water excess. According to Guenni et al. [5], among the most common Brachiaria species, only B. brizantha showed reduced $L A$ when subjected to severe dehydration stress. The final leaf size depends on cells division and expansion, and it has been shown that dehydration stress affects leaf area by reducing cell number and size [24]. 
Table 3. Effect of soil water pressure head on leaf area (Brachiaria brizantha cultivars) for the three cutting periods.

\begin{tabular}{|c|c|c|c|c|c|c|}
\hline \multirow{4}{*}{ Cultivar } & \multicolumn{6}{|c|}{ Leaf Area ${ }^{1}\left(\mathrm{~cm}^{2} \cdot\right.$ pot $\left.^{-1}\right)$} \\
\hline & \multicolumn{6}{|c|}{ First cut (40 DAE) } \\
\hline & \multicolumn{6}{|c|}{ Soil water pressure head- $-h(\mathrm{kPa})$} \\
\hline & 0 & -10 & -20 & -30 & -40 & -50 \\
\hline Braúna & $609 \mathrm{~b} \pm 157$ & $2329 \mathrm{~b} \pm 58$ & $1982 b \pm 125$ & $1826 a \pm 65$ & $1267 \mathrm{a} \pm 308$ & $939 a \pm 29$ \\
\hline Paiaguás & $948 \mathrm{ab} \pm 160$ & $3190 \mathrm{a} \pm 220$ & $2892 \mathrm{a} \pm 204$ & $1620 \mathrm{a} \pm 390$ & $1632 \mathrm{a} \pm 295$ & $1020 \mathrm{a} \pm 150$ \\
\hline Piatã & $1241 \mathrm{a} \pm 121$ & $2910 \mathrm{a} \pm 362$ & $2336 \mathrm{~b} \pm 281$ & $2254 \mathrm{~b} \pm 269$ & $1553 \mathrm{a} \pm 250$ & $1138 \mathrm{a} \pm 222$ \\
\hline \multirow{3}{*}{ Cultivar } & \multicolumn{6}{|c|}{ Second cut (70 DAE) } \\
\hline & \multicolumn{6}{|c|}{ Soil water pressure head- $-h(\mathrm{kPa})$} \\
\hline & 0 & -10 & -20 & -30 & -40 & -50 \\
\hline Braúna & $1581 \mathrm{~b} \pm 404$ & $4222 \mathrm{a} \pm 165$ & $3826 \mathrm{a} \pm 313$ & $3427 \mathrm{a} \pm 339$ & $1960 \mathrm{a} \pm 474$ & $999 a \pm 398$ \\
\hline Paiaguás & $1403 \mathrm{~b} \pm 405$ & $4194 \mathrm{a} \pm 700$ & $4042 \mathrm{a} \pm 650$ & $1632 b \pm 575$ & $1930 \mathrm{a} \pm 316$ & $690 \mathrm{a} \pm 299$ \\
\hline Piatã & $2750 \mathrm{a} \pm 442$ & $4235 \mathrm{a} \pm 600$ & $3241 \mathrm{a} \pm 318$ & $3162 \mathrm{a} \pm 593$ & $1930 \mathrm{a} \pm 417$ & $1005 \mathrm{a} \pm 423$ \\
\hline Cultivar & \multicolumn{6}{|c|}{ Third cut (100 DAE) } \\
\hline Braúna & \multicolumn{6}{|c|}{$2150 \mathrm{a} \pm 1412$} \\
\hline Paiaguás & \multicolumn{6}{|c|}{$1752 a \pm 1476$} \\
\hline Piatã & \multicolumn{6}{|c|}{$2211 \mathrm{a} \pm 1344$} \\
\hline
\end{tabular}

${ }^{1} \pm$ standard deviation of the four replicas. Cultivars means followed by the same letters under the same treatment (pressure head) and cuts do not differ from each other statistically according to the Tukey's test at $p<0.05$.
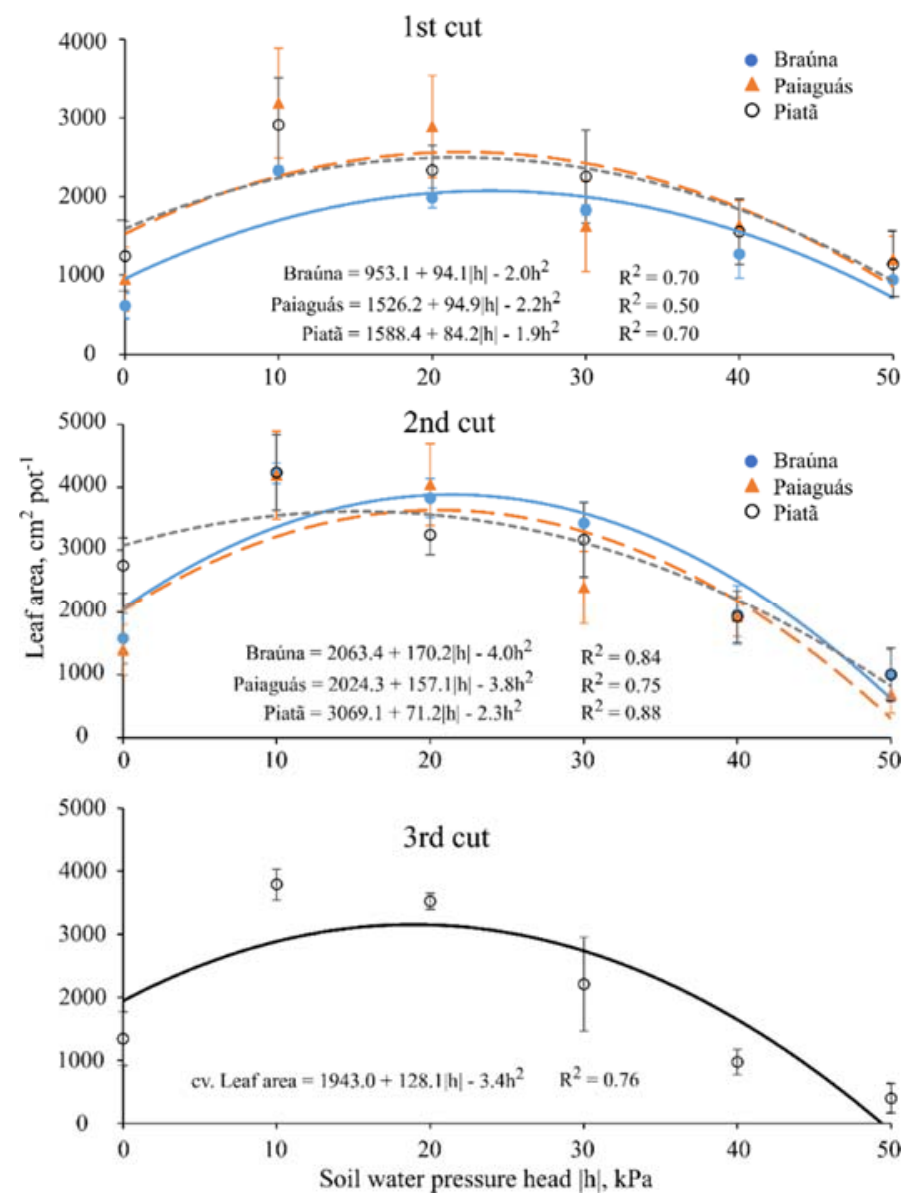

Figure 3. Regression models relating soil water pressure head to leaf area of Brachiaria brizantha cultivars for the three cutting periods (40, 70, and $100 \mathrm{DAE})$. Error bars correspond to the standard deviation of the four replicas. 


\subsection{Bulk Leaf Succulence}

For this variable, cultivar was the main source of variation, with Piatã and BRS Paiaguás obtaining higher succulence degree than that of the cultivar MG13 Braúna at both cut periods (Table 4). No interaction effect was detected between the $h$ treatments and the cultivar. In general, the cultivars that developed higher leaf area presented higher succulence degree as well. Actual leaf succulence degree is a proxy of adequate cell turgor, which is a well-known property that promotes plant growth at cell and organ levels [24-26]. The higher succulence degree observed for the cultivars Piatã and BRS Paiaguás was in agreement with plant height measurements, where these two cultivars obtained superior plant height values for most of the pressure head treatments, which may have been stimulated by higher cell turgor. A general regression model was fitted to the pooled data from all three cultivars of each evaluated cutting period. For the first cut, a quadratic regression model showed that higher leaf succulence occurs between the pressure head range $-20 \mathrm{kPa}$ and $-30 \mathrm{kPa}$; on the other hand, a highly linear regression model fitted to the data from the third cut, showing a reduction trend of leaf succulence degree as the soil became drier (Figure 4).

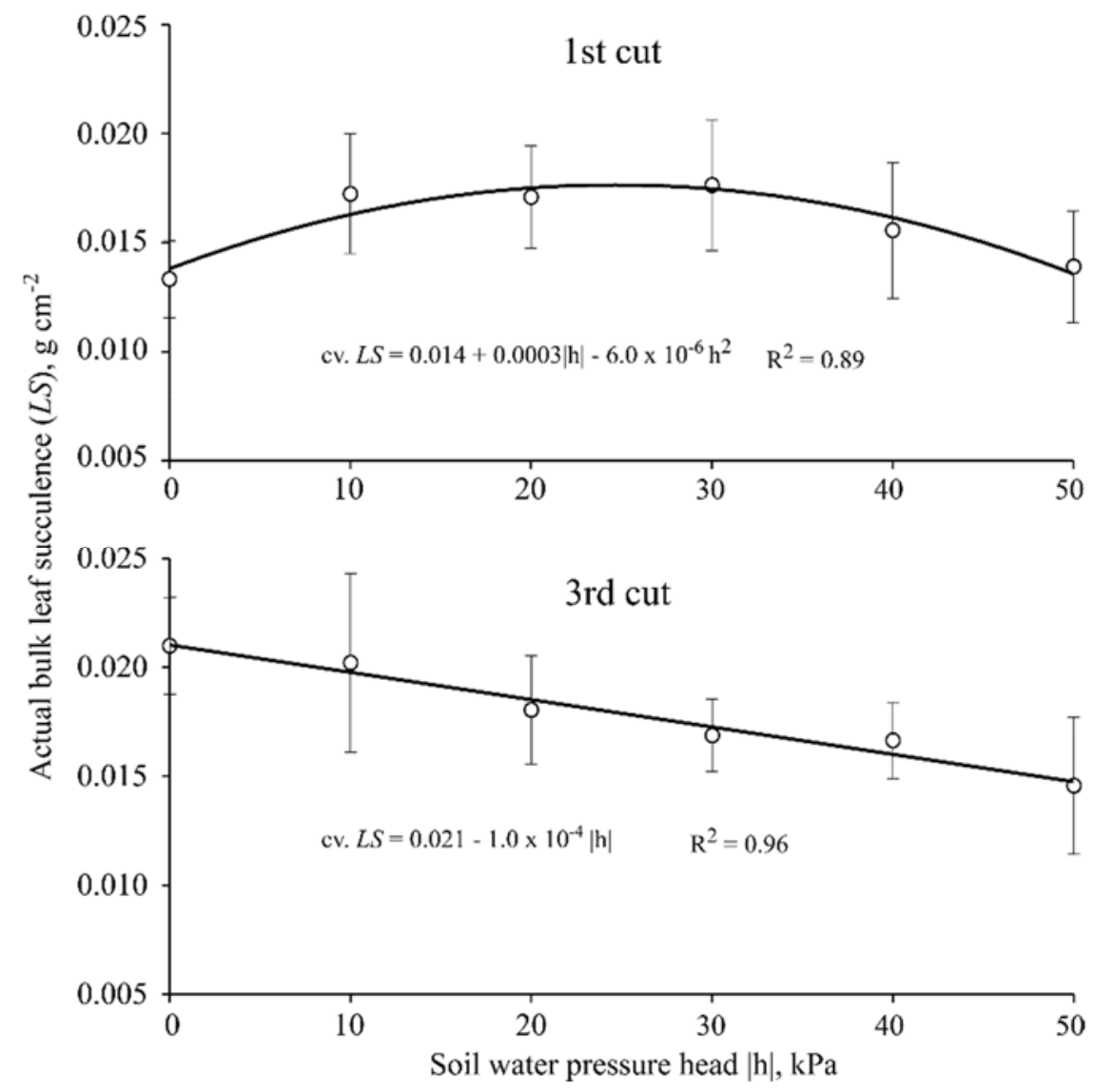

Figure 4. Regression models relating soil water pressure head to bulk leaf succulence of Brachiaria brizantha cultivars for the first and third cutting periods (40 and $70 \mathrm{DAE}$ ). Error bars correspond to the standard deviation of the four replicas. 
Table 4. Effect of soil water pressure head on leaf succulence (Brachiaria brizantha cultivars) for the first and third cutting periods.

\begin{tabular}{cc}
\hline & Bulk Leaf Succulence ${ }^{\mathbf{1}}\left(\mathbf{g} \cdot \mathbf{c m}^{-\mathbf{2}}\right)$ \\
\hline Cultivar & First cut $(40 \mathrm{DAE})$ \\
\hline Braúna & $0.013 \mathrm{~b} \pm 0.001$ \\
Paiaguás & $0.017 \mathrm{a} \pm 0.003$ \\
Piatã & $0.017 \mathrm{a} \pm 0.002$ \\
\hline Cultivar & Third cut $(100 \mathrm{DAE})$ \\
\hline Braúna & $0.015 \mathrm{~b} \pm 0.002$ \\
Paiaguás & $0.017 \mathrm{ab} \pm 0.001$ \\
Piatã & $0.020 \mathrm{a} \pm 0.003$ \\
\hline
\end{tabular}

$1 \pm$ standard deviation of the four replicas. Cultivars means followed by the same letters under the same treatment (pressure head) and cuts do not differ from each other statistically according to the Tukey's test at $p<0.05$.

\subsection{Aboveground Dry Biomass}

So far, we have discussed parameters related to plant growth (phenotypic traits), and consequently to biomass yield. On the other hand, aboveground dry biomass is likely the most interesting variable regarding the potential yield of pasture species, for either grazing or ensiling purposes [11]. Although, from a nutritional standpoint, biomass yield alone is insufficient to assess the value of a cultivar regarding ruminants' growth performance. In this sense, additional studies are needed to assess the nutritional aspects of these cultivars while subjected to varying soil water availability. According to our statistical analysis, in general, the cultivar Piatã obtained slightly higher aboveground dry biomass yield than its counterparts to most of the evaluated scenarios. Rare exceptions occurred at $h<-20 \mathrm{kPa}$, where the cultivar Piatã was outperformed by its counterparts (Table 5 and Figure 5).

Table 5. Effect of soil water pressure head on aboveground dry biomass (Brachiaria brizantha cultivars) for the three cutting periods.

\begin{tabular}{|c|c|c|c|c|c|c|}
\hline \multirow{4}{*}{ Cultivar } & \multicolumn{6}{|c|}{ Aboveground Dry Biomass ${ }^{1}$ (g) } \\
\hline & \multicolumn{6}{|c|}{ First cut (40 DAE) } \\
\hline & \multicolumn{6}{|c|}{ Soil water pressure head $-h(\mathrm{kPa})$} \\
\hline & 0 & -10 & -20 & -30 & -40 & -50 \\
\hline Braúna & $2.5 \mathrm{a} \pm 0.4$ & $8.8 \mathrm{~b} \pm 1.1$ & $1.5 b \pm 0.5$ & $8.0 \mathrm{a} \pm 1.3$ & $6.2 \mathrm{a} \pm 2.1$ & $4.0 \mathrm{~b} \pm 1.7$ \\
\hline Paiaguás & $3.8 \mathrm{a} \pm 1.1$ & $12.7 \mathrm{a} \pm 2.1$ & $7.4 \mathrm{a} \pm 2.1$ & $8.2 \mathrm{a} \pm 2.1$ & $5.8 \mathrm{~b} \pm 2.1$ & $4.5 \mathrm{a} \pm 1.1$ \\
\hline Piatã & $3.7 \mathrm{a} \pm 1.2$ & $12.0 \mathrm{a} \pm 0.8$ & $7.4 \mathrm{a} \pm 0.8$ & $8.2 \mathrm{a} \pm 1.6$ & $5.8 \mathrm{~b} \pm 1.7$ & $3.5 b \pm 0.9$ \\
\hline \multirow{3}{*}{ Cultivar } & \multicolumn{6}{|c|}{ Second cut (70 DAE) } \\
\hline & \multicolumn{6}{|c|}{ Soil water pressure head $-h(\mathrm{kPa})$} \\
\hline & 0 & -10 & -20 & -30 & -40 & -50 \\
\hline Braúna & $8.2 b \pm 2.9$ & $27.9 \mathrm{a} \pm 2.4$ & $22.9 \mathrm{ab} \pm 2.4$ & $20.8 \mathrm{a} \pm 2.5$ & $12.3 \mathrm{a} \pm 4.3$ & $6.0 \mathrm{a} \pm 2.2$ \\
\hline Paiaguás & $8.1 b \pm 2.6$ & $24.8 \mathrm{a} \pm 6.4$ & $27.5 \mathrm{a} \pm 5.0$ & $9.8 \mathrm{~b} \pm 2.1$ & $12.1 \mathrm{a} \pm 2.1$ & $5.0 \mathrm{a} \pm 2.5$ \\
\hline Piatã & $21.5 \mathrm{a} \pm 3.1$ & $27.5 \mathrm{a} \pm 7.0$ & $19.8 b \pm 2.6$ & $20.3 \mathrm{a} \pm 3.5$ & $12.8 \mathrm{a} \pm 1.9$ & $7.7 \mathrm{a} \pm 2.7$ \\
\hline Cultivar & \multicolumn{6}{|c|}{ Third cut (100 DAE) } \\
\hline Braúna & \multicolumn{6}{|c|}{$18.4 \mathrm{ab} \pm 14.1$} \\
\hline Paiaguás & \multicolumn{6}{|c|}{$15.0 \mathrm{~b} \pm 13.7$} \\
\hline Piatã & \multicolumn{6}{|c|}{$18.9 \mathrm{a} \pm 12.4$} \\
\hline
\end{tabular}

\footnotetext{
${ }^{1} \pm$ standard deviation of the four replicas. Cultivars' means followed by the same letters under the same treatment
} (pressure head) and cuts do not differ from each other statistically according to the Tukey's test at $p<0.05$. 

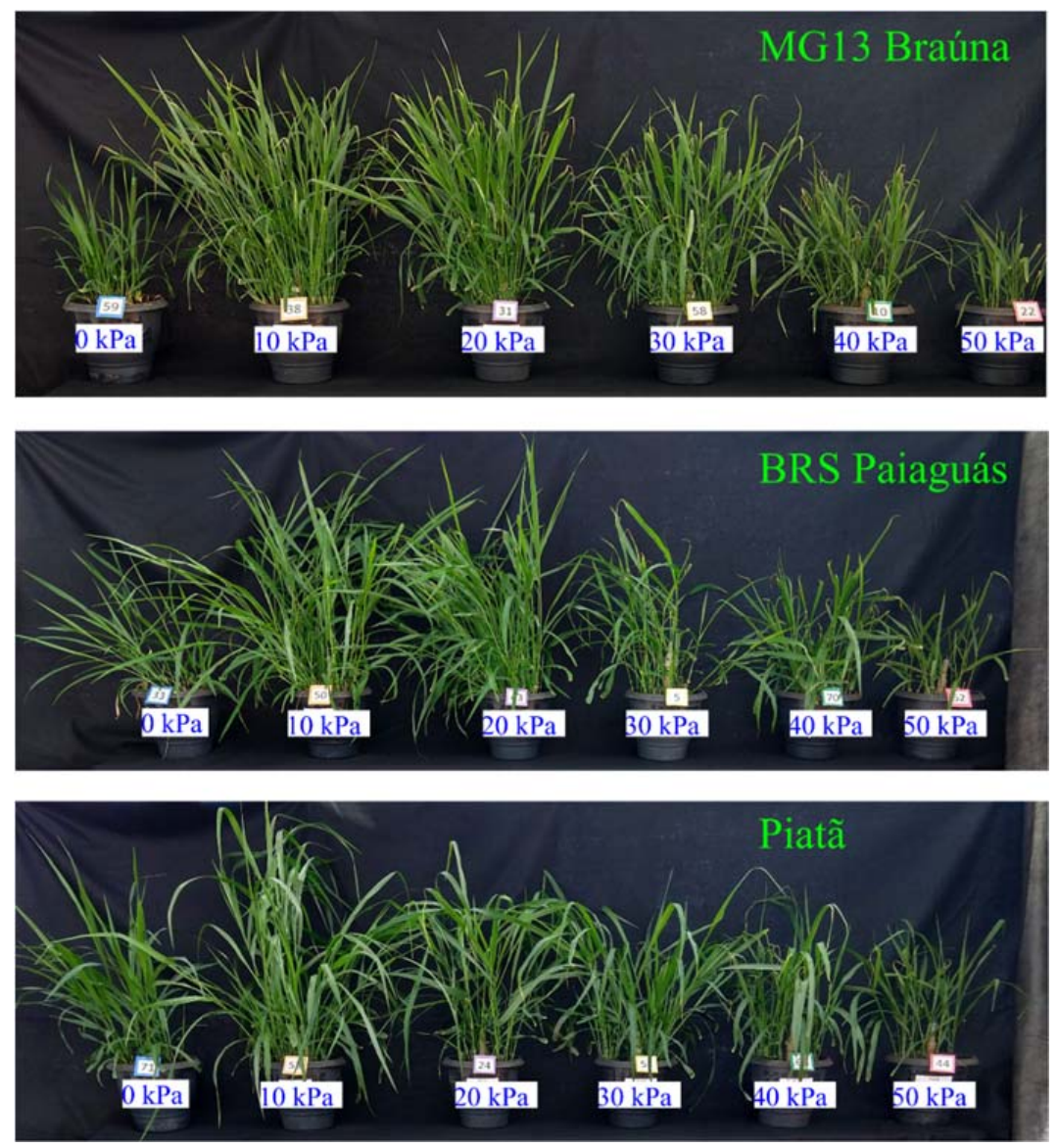

Figure 5. Cultivars of Brachiaria brizantha, MG13 Braúna, BRS Paiaguás, and Piatã at soil water pressure head $|\mathrm{h}| 0,10,20,30,40$, and $50 \mathrm{kPa}$ on the 30 th day after the first cut (70 DAE).

Interaction effects between $h$ treatments and cultivars were observed for the first and second cuts only, where quadratic regression models show that the pressure head value close to $-20 \mathrm{kPa}$ gave the highest yields of aboveground dry biomass (Figure 6), while at higher or lower pressure head the aboveground biomass yield was constrained. This result indicates that both cultivars lack the trait to cope with waterlogging and moderate dehydration stresses. Guenni et al. [5] investigating dehydration stress on Brachiaria species found that $B$. brizantha is among the most susceptible ones, showing the earliest dehydration stress onset, and consequently, the largest yield reduction. Meirelles et al. [6] showed that established and grazed B. brizantha pasture responds rapidly to the first water pulse of the rainy season, increasing live phytomass from 30 (end of dry season) to $100 \mathrm{~g} \cdot \mathrm{m}^{-2}$ (after the first rainfall events).

Given the high water demand by the B. brizantha, as shown in our results and elsewhere $[5,6,10]$, it is expected that these three analyzed cultivars have the potential to shape the soil water balance components of large areas (e.g., reduce water infiltration while transpiration rates are increased, thus, depleting soil water content).

\subsection{Root Dry Biomass}

Root dry biomass (which was measured at the third cut) did not differ between cultivars and neither was any interaction effect of soil pressure heads over cultivars detected. Although the highest observed root dry biomass was at $h=-10 \mathrm{kPa}$, it is worth noting that under soil saturation root dry biomass was higher than that at $h<-30 \mathrm{kPa}$ (Figure 7). 

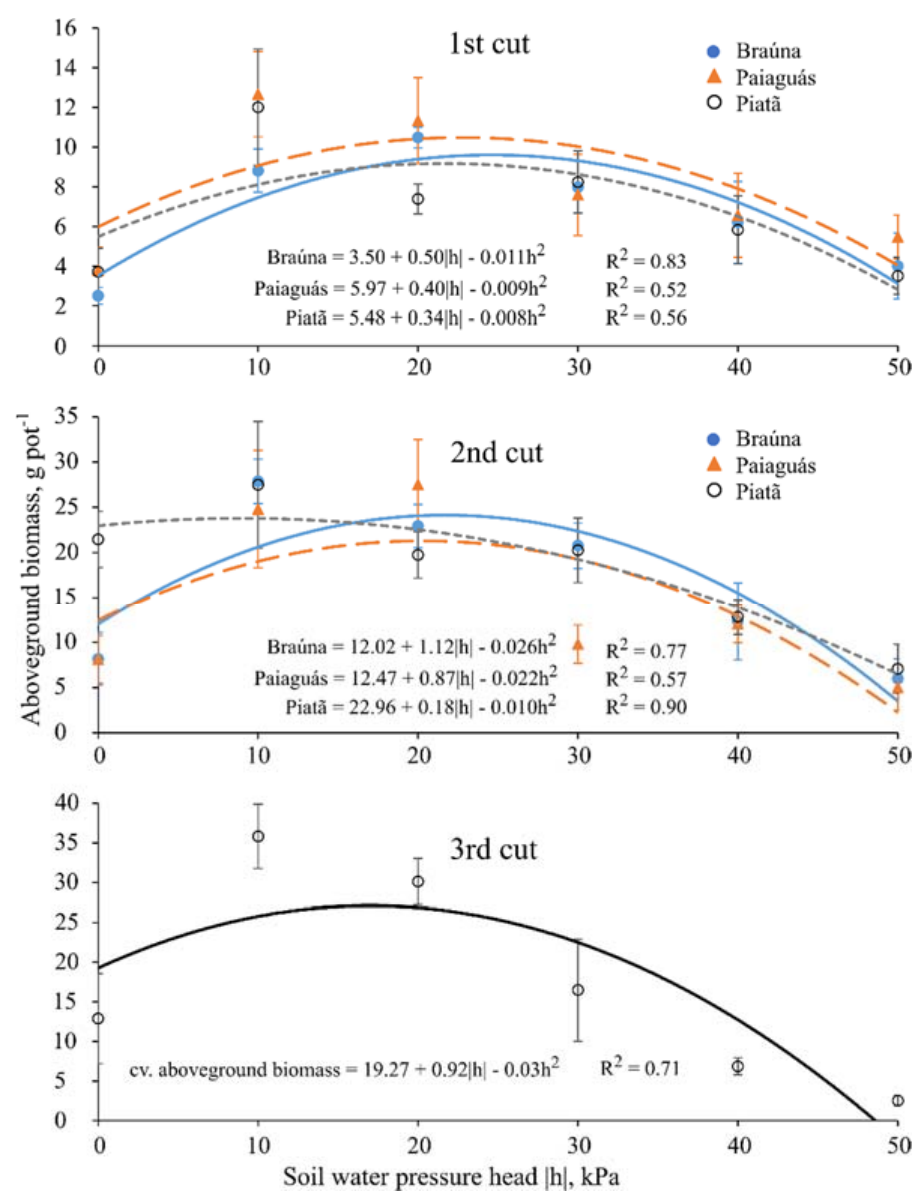

Figure 6. Regression models relating soil water pressure head to aboveground dry biomass of Brachiaria brizantha cultivars for the three cutting periods (40, 70, and 100 DAE). Error bars correspond to the standard deviation of the four replicas.

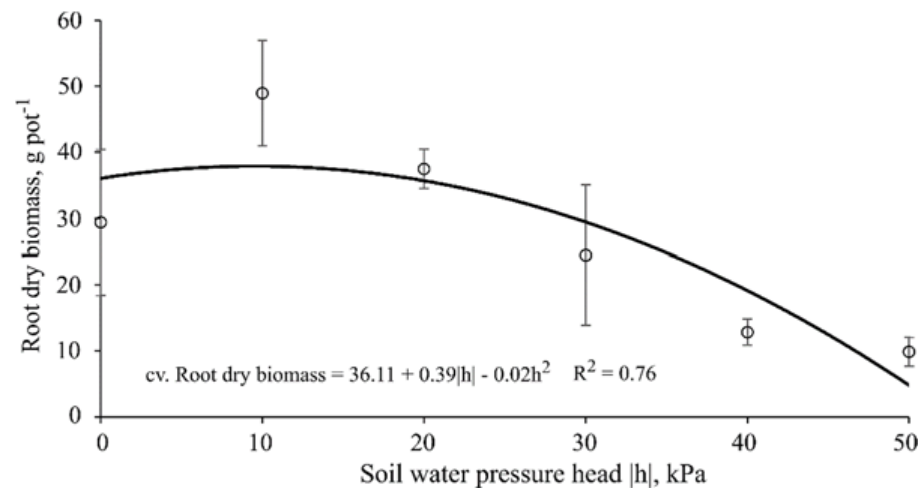

Figure 7. Regression models relating soil water pressure head to root dry biomass of Brachiaria brizantha cultivars for the third cutting period (100 DAE).

Root biomass is directly related to root length density, an important property in root water uptake processes [27]. However, sole use of total root biomass quantity may produce biased information regarding root water uptake efficiency, which depends on not only biomass (root presence) but mostly on root activity. When comparing the results of aboveground dry biomass of the third cut to that of root dry biomass at this same cut, one can see that at $h-40$ and $-50 \mathrm{kPa}$ root biomass was almost double that of the aboveground biomass. A similar result was observed at soil saturation. The highest ratio (0.8) between above and belowground dry biomass was recorded at $h=-20 \mathrm{kPa}$, and the lowest 
(0.25) at $h=-50 \mathrm{kPa}$, indicating that under dehydration stress the evaluated B. brizantha cultivars invested more resources on root biomass than aboveground biomass (Figure 8), which is likely an attempt to increase root water access. Nonetheless, as discussed in Guenni et al. [5], in some cases low shoot/root biomass ratio is poorly correlated to root water uptake efficiency.
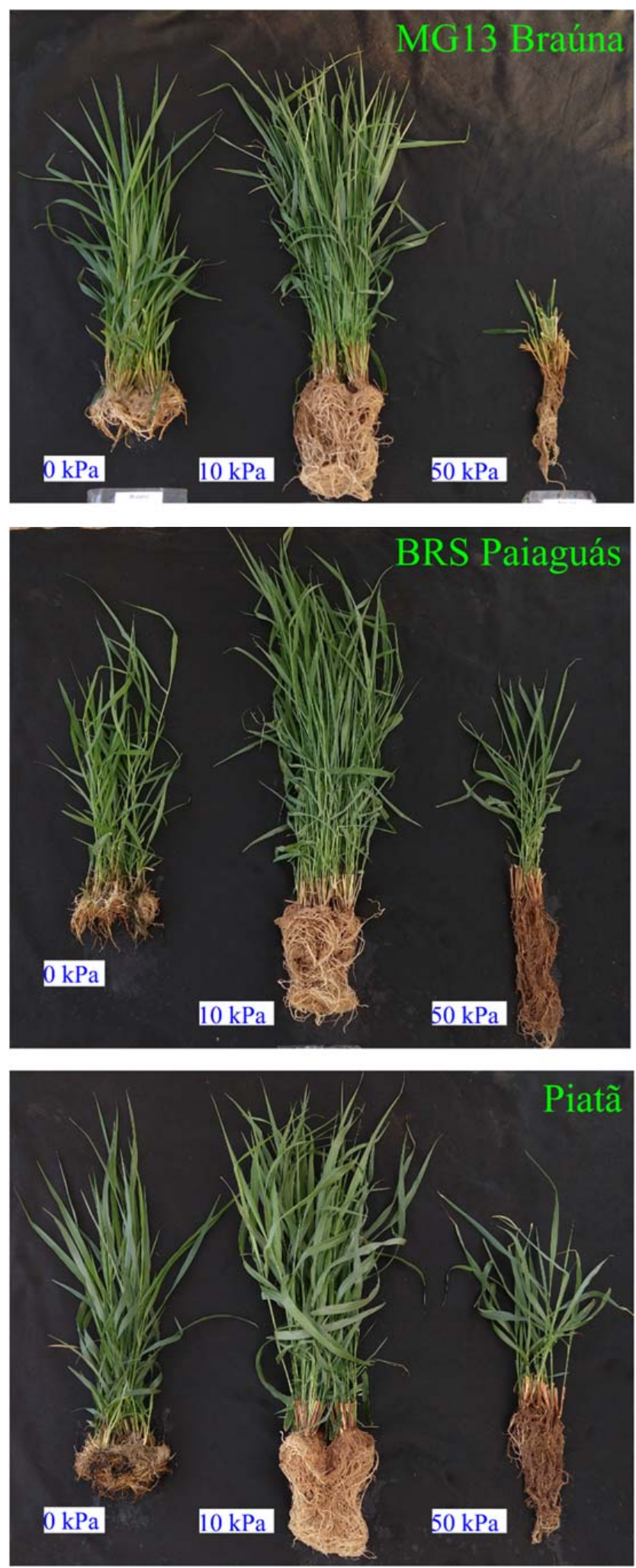

Figure 8. Root development of Brachiaria brizantha cultivars (MG13 Braúna, BRS Paiaguás, and Piatã) at soil water pressure head $|\mathrm{h}| 0,10$, and $50 \mathrm{kPa}$ on the $100 \mathrm{DAE}$ (third cut). 
The relation between root density and water uptake efficiency can be even more complex at heterogeneous field scale, where soil hydraulic properties (water retention and hydraulic conductivity) play a paramount role in the soil water flow towards roots. Based on soil physics processes, water flow in the vadose zone is a passive response to hydraulic gradients developed between the bulk soil and the root surface. Consequently, larger root biomass (a proxy of root density) drives water flow at potential rates under small pressure head gradients, since the sum of all flux densities from individual roots is sufficient to supply the potential atmospheric demands, and thus postpone the onset of drought stress. On the other hand, under restricted root development, larger hydraulic gradients are necessary in order to attain flux densities compatible to atmospheric demand $[28,29]$. The hydraulic gradients developed in the vadose zone are also highly influenced by the unsaturated hydraulic conductivity $\mathrm{K}$ (h), where depending on the soil hydraulic properties, a larger hydraulic gradient may be necessary to compensate small drops on $\mathrm{K}(h)$ [30].

\subsection{Water Use Efficiency}

In the following we present the results regarding water use efficiency (WUE) calculated at the second cutting period (70 DAE), Table 6 and Figure 9. The detected interaction effect of $h$ treatments on WUE shows that the Piatã cultivar obtained the most regular averages for all pressure head treatments, while the other cultivars exhibited larger oscillation, especially the BRS Paiaguás. The Piatã cultivar obtained its highest WUE value at soil saturation, which is in agreement with the aboveground dry biomass presented in Figure 6 for the second cut, whereas the other cultivars attained their highest WUE at $h$ ranging from -10 to $-20 \mathrm{kPa}$. Guenni et al. [10] showed instantaneous photosynthetic water use efficiency to be constant and similar for several Brachiaria species subjected to dehydration stress treatments.

Controlled greenhouse experiments permit higher WUE value attainment than field conditions for allowing precise water replenishment (reducing evaporation losses), maintaining soil water potential closer to the desired range. Accordingly, other studies investigating the WUE of planted and natural pasture species have reported lower WUE values than those reported in Table 6. Snyman [31] reported a WUE average of $0.78 \mathrm{~kg} \cdot \mathrm{m}^{-3}$ for six dryland planted pasture species. White and Snow [32] simulated WUE for different irrigation scenarios, climate, and soil types, with results ranging from $1-3 \mathrm{~kg} \cdot \mathrm{m}^{-3}$. As an example of how soil water availability can strongly control WUE, Moot et al. [33] found WUE ranging from below $1 \mathrm{~kg} \cdot \mathrm{m}^{-3}$ to $4 \mathrm{~kg} \cdot \mathrm{m}^{-3}$ for different combinations of pasture species and soil types with very different water availability patterns throughout the year.

As discussed in Molden et al. [34] and Bodner et al. [35], the knowledge of the most adequate soil water content range for plant growth is essential for the optimization of growth factor resources (e.g., water, nutrients, light) of either rainfed or irrigated crops, which are responsible for controlling the phenotypic expression of crops.

Table 6. Effect of soil water pressure head on water use efficiency (Brachiaria brizantha cultivars) for the second cutting period.

\begin{tabular}{ccccccc}
\hline & \multicolumn{5}{c}{ Water Use Efficiency ${ }^{\mathbf{1}} \mathbf{( k g \cdot \mathbf { m } ^ { - 3 } )}$} \\
\hline \multirow{2}{*}{ Cultivars } & \multicolumn{5}{c}{ Second cut $(70 \mathrm{DAE})$} \\
\cline { 2 - 7 } & 0 & 10 & 20 & 30 & 40 & 50 \\
\hline Braúna & $2.19 \mathrm{~b} \pm 0.7$ & $6.10 \mathrm{a} \pm 0.4$ & $5.55 \mathrm{a} \pm 0.6$ & $5.25 \mathrm{a} \pm 0.1$ & $4.08 \mathrm{a} \pm 1.2$ & $3.47 \mathrm{a} \pm 1.3$ \\
Paiaguás & $2.03 \mathrm{~b} \pm 0.6$ & $5.50 \mathrm{~b} \pm 1.0$ & $5.19 \mathrm{a} \pm 0.6$ & $3.26 \mathrm{~b} \pm 0.5$ & $3.61 \mathrm{a} \pm 0.6$ & $2.70 \mathrm{a} \pm 1.4$ \\
Piatã & $5.63 \mathrm{a} \pm 0.9$ & $5.55 \mathrm{a} \pm 1.1$ & $5.00 \mathrm{a} \pm 0.5$ & $4.98 \mathrm{a} \pm 0.7$ & $4.02 \mathrm{a} \pm 0.7$ & $3.62 \mathrm{a} \pm 1.4$ \\
\hline
\end{tabular}

${ }^{1} \pm$ standard deviation of the four replicas. Cultivars means followed by the same letters under the same treatment (pressure head) and cuts do not differ from each other statistically according to the Tukey's test at $p<0.05$. 


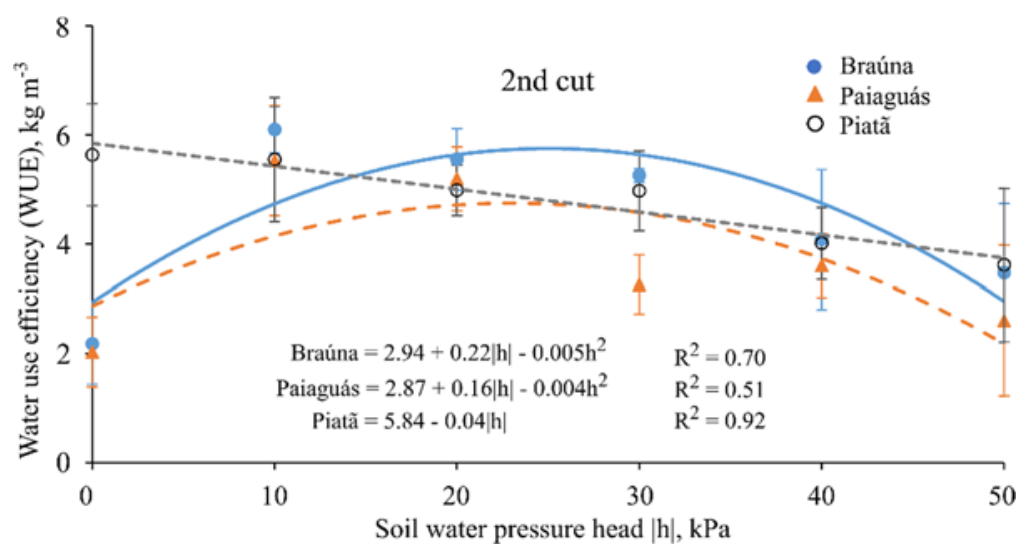

Figure 9. Regression models relating soil water pressure head to water use efficiency of Brachiaria brizantha cultivars for the second cutting period (70 DAE). Error bars correspond to the standard deviation of the four replicas.

\section{Conclusions}

The main findings of our research on evaluating different Brachiaria brizantha cultivars regarding their phenotypic traits and yield aspects, allow us to conclude that:

1. The low drought-resistant trait observed for all evaluated Brachiaria brizantha cultivars, grown on Fluvisol, indicates the need for releasing of better-adapted cultivars to cope with scenarios of reduced soil water availability typical of drought-prone regions.

2. Regarding the phenotypic traits response, the cultivar Piatã, followed closely by the cultivar BRS Paiaguás, showed superior results to most of the evaluated scenarios.

3. The evaluated Brachiaria brizantha cultivars grown in a coarse-textured soil achieved higher performance at soil water pressure heads $(h)$ within the range $-15 \mathrm{kPa}$ and $-25 \mathrm{kPa}$; however, given the high dependence of soil water availability on soil hydraulic properties, other soil types should be tested in experiments under natural field conditions.

Author Contributions: Conceptualization, C.T.R.d.S., E.M.B.-S., and T.J.d.A.d.S.; methodology, E.M.B.-S., T.J.d.A.d.S., and C.T.R.d.S.; formal analysis, E.M.B.-S, T.J.d.A.d.S, C.T.R.d.S., E.A.R.P., A.P.F.F., and J.V.J.; investigation, C.T.R.d.S.; resources, E.M.B.-S., T.J.d.A.d.S. and J.V.J.; data curation, C.T.R.d.S.; writing-original draft preparation, C.T.R.d.S. and E.A.R.P.; writing-review and editing, E.A.R.P. and A.P.F.F.; visualization, E.A.R.P., A.P.F.F., J.V.J., and E.M.B.-S.; supervision, E.M.B.-S. and T.J.d.A.d.S.; project administration, E.M.B.-S. and T.J.d.A.d.S.; funding acquisition, E.M.B.-S and T.J.d.A.d.S. All authors have read and agreed to the published version of the manuscript.

Funding: This research received no external funding.

Acknowledgments: To CNPq (National Council for Scientific and Technological Development, Brazil), for research productivity fellowships to second and third authors; to CAPES (Coordination for the Improvement of Higher Education Personnel, Brazil) for the Master degree scholarship granted to the first author and for the postdoctoral fellowship to the sixth author.

Conflicts of Interest: The authors declare no conflict of interest.

\section{References}

1. Bowman, M.S.; Soares-Filho, B.S.; Merry, F.D.; Nepstad, D.C.; Rodrigues, H.; Almeida, O.T. Persistence of cattle ranching in the Brazilian Amazon: A spatial analysis of the rationale for beef production. Land Use Pol. 2012, 29, 558-568. [CrossRef]

2. Jank, L.; Barrios, S.C.; Valle, C.B.; Simeão, R.M.; Alves, G.F. The value of improved pastures to Brazilian beef production. Crop. Pest. Sci. 2014, 65, 1132-1137. [CrossRef]

3. Barreto, A.G.O.P.; Berndes, G.; Sparovek, G.; Wirsenius, S. Agricultural intensification in Brazil and its effects on land-use patterns: An analysis of the 1975-2006 period. Global Change Biol. 2013, 19, 1804-1815. [CrossRef] 
4. Baruch, Z. Responses to drought and flooding in tropical forage grasses I. Biomass allocation, leaf growth and mineral nutrients. Plant. Soil 1994, 164, 87-96. [CrossRef]

5. Guenni, O.; Marín, D.; Baruch, Z. Response to drought of five Brachiaria species. I. Biomass production, leaf growth, root distribution, water use and forage quality. Plant. Soil 2002, 243, 229-241. [CrossRef]

6. Meirelles, M.L.; Franco, A.C.; Farias, S.E.M.; Bracho, R. Evapotranspiration and plant-Atmospheric coupling in a Brachiaria brizantha pasture in the Brazilian savannah region. Grass For. Sci. 2011, 66, 206-213. [CrossRef]

7. Foley, J.J.A.; Ramankutty, N.; Brauman, K.A.; Cassidy, E.S.; Gerber, J.S.; Johnston, M.; Mueller, N.D.; O'Connell, C.; Ray, D.K.; West, P.C.; et al. Solutions for a cultivated planet. Nature 2011, 478, 337-342. [CrossRef]

8. MAPA/AGE. Projections of Agribusiness-Brazil 2009/10 to 2019/20 Ministry of Agriculture, Livestock and Food Supply_Strategic Management Advisory Board; MAPA/AGE: Brasília, Brazil, 2010; p. 48.

9. ANUALPEC. 'Anuário da Pecuária Brasileira' (Yearbook of Brazilian Livestock); Instituto FNP, AGRA FNP Pesquisas Ltda: São Paulo, Brazil, 2015.

10. Guenni, O.; Baruch, Z.; Marín, D. Response to drought of five Brachiaria species. II. Water relations and leaf gas exchange. Plant. Soil 2004, 258, 249-260. [CrossRef]

11. Cezário, A.S.; Ribeiro, K.G.; Santos, S.A.; Valadares Filho, S.C.; Pereira, O.G. Silages of Brachiaria brizantha cv. Marandu harvested at two regrowth ages: Microbial inoculant responses in silage fermentation, ruminant digestion and beef cattle performance. Anim. Feed Sci. Technol. 2015, 208, 33-43. [CrossRef]

12. Orrico Junior, M.A.P.; da Silveira, A.P.; Orrico, A.C.A.; Schwingel, A.W.; Carnavali, P.L.; Alves, D.C. Use of Organic Compost for the Fertilization of Piatã and Paiaguás Grasses: Effects of Dose on Morphogenetic, Structural, Nutritional, and Productive Characteristics. Compost Sci. Utiliz. 2018, 26, 201-208. [CrossRef]

13. Santos, A.J.B.; Quesada, C.A.; da Silva, G.T.; Maia, J.F.; Miranda, H.S.; Miranda, A.C.; Lloyd, J. High rates of net ecosystem carbon assimilation by Brachiaria pasture in the Brazilian Cerrado. Glob. Chang. Biol. 2004, 10, 877-885. [CrossRef]

14. Lascano, C.E. Managing the grazing resource for animal production in savannas of tropical America. Trop. Grassl. 1991, 25, 66-72.

15. Pizarro, E.A.; do Valle, C.B.; Keller-Grein, G.; Schultze-Kraft, R.; Zimmer, A.H. Experiencia regional con Brachiaria: Región de América Tropical-Sabanas. In Brachiaria: Biología, Agronomía y Mejoramiento; Miles, J.W., Maass, B.L., do Valle, C.B., Eds.; CIAT: Cali, Colombia; EMBRAPA/CNPGC: Campo Grande, Brazil, 1998; pp. 247-269.

16. Alvares, C.A.; Stape, J.L.; Sentelhas, P.C.; Gonçalves, J.L.M.; Sparovek, G. Köppen's climate classification map for Brazil. Meteorol. Z. 2014, 22, 711-728. [CrossRef]

17. IUSS Working Group WRB. World Reference Base for Soil Resources 2014, Update 2015. International Soil Classification System for Naming Soils and Creating Legends for Soil Maps; World Soil Resources Reports 106; FAO: Rome, Italy, 2015.

18. Van Genuchten, M.T. A closed-form equation for predicting the hydraulic conductivity of unsaturated soils. Soil Sci. Soc. Am. J. 1980, 44, 892-897. [CrossRef]

19. Van Genuchten, M.T.; Leij, F.J.; Yates, S.R. The RETC Code for Quantifying the Hydraulic Functions of Unsaturated Soils, Version 1.0; EPA Report 600/2-91/065; U.S. Salinity Laboratory, USDA, ARS: Riverside, CA, USA, 1991.

20. Geerts, S.; Raes, D. Deficit irrigation as an on-farm strategy to maximize crop water productivity in dry areas. Agric. Water Manag. 2009, 96, 1275-1284. [CrossRef]

21. Bastiaanssen, W.G.M.; Steduto, P. The water productivity score (WPS) at global and regional level: Methodology and first results from remote sensing measurements of wheat, rice and maize. Sci. Total Environ. 2017, 575, 595-611. [CrossRef]

22. De Jong van Lier, Q.; Pinheiro, E.A.R.; Inforsato, L. A One-Dimensional Physically Based Approach to Predict Soil Profile Aeration Requirements. Soil Sci. Soc. Am. J. 2018, 82, 593-600. [CrossRef]

23. Bailey-Serres, J.; Voesenek, L.A.C.J. Flooding stress: Acclimations and genetic diversity. Annu. Rev. Plant. Biol. 2008, 59, 313-339. [CrossRef]

24. Skirycz, A.; Inzé, D. More from less: Plant growth under limited water. Curr. Op. Biotechnol. 2010, 21, 197-203. [CrossRef]

25. Geng, Y.; Wu, R.; Wee, C.W.; Xie, F.; Wei, X.; Chan, P.M.Y.; Tham, C.; Duan, L.; Dinneny, J.R. A spatio-temporal understanding of growth regulation during the salt stress response in Arabidopsis. Plant. Cell 2013, 25, 2132-2154. [CrossRef] 
26. Feng, W.; Lindner, H.; Robbins, N.E., II; Dinneny, J.R. Growing out of stress: The role of cell- and organ-scale growth control in plant water-stress responses. Plant. Cell 2016, 28, 1769-1782. [CrossRef]

27. Metselaar, K.; Pinheiro, E.A.R.; de Jong van Lier, Q. Mathematical Description of Rooting Profiles of Agricultural Crops and its Effect on Transpiration Prediction by a Hydrological Model. Soil Syst. 2019, 3, 44. [CrossRef]

28. De Jong van Lier, Q.; Metselaar, K.; Van Dam, J.C. Root Water Extraction and Limiting Soil Hydraulic Conditions Estimated by Numerical Simulation. Vadose Zone J. 2006, 5, 1264-1277. [CrossRef]

29. Pinheiro, E.A.R.; de Jong van Lier, Q.; Metselaar, K. A Matric Flux Potential Approach to Assess Plant Water Availability in Two Climate Zones in Brazil. Vadose Zone J. 2018, 17, 160083. [CrossRef]

30. Pinheiro, E.A.R.; de Jong van Lier, Q.; Inforsato, L.; Šimůnek, J. Measuring full-range soil hydraulic properties for the prediction of crop water availability using gamma-ray attenuation and inverse modeling. Agric. Water Manag. 2019, 216, 294-305. [CrossRef]

31. Snyman, H.A. Evapotranspiration, water-use efficiency and quality of six dryland planted pasture species and natural vegetation, in a semi-arid rangeland. Afr. J. Range For. Sci. 1994, 11, 82-88. [CrossRef]

32. White, T.A.; Snow, V.O. A modelling analysis to identify plant traits for enhanced water-use efficiency of pasture. Crop Past. Sci. 2012, 63, 63-76. [CrossRef]

33. Moot, D.J.; Brown, H.E.; Pollock, K.; Mills, A. Yield and water use of temperate pastures in summer dry environments. Proc. N. Z. Grass. Assoc. 2008, 70, 51-57.

34. Molden, D.; Oweis, T.; Steduto, P.; Bindraban, P.; Hanjra, M.A.; Kijne, J. Improving agricultural water productivity: Between optimism and caution. Agric. Water Manag. 2010, 97, 528-535. [CrossRef]

35. Bodner, G.; Nakhforoosh, A.; Kaul, H.P. Management of crop water under drought: A review. Agron. Sustain. Dev. 2015, 35, 401-442. [CrossRef]

(C) 2020 by the authors. Licensee MDPI, Basel, Switzerland. This article is an open access article distributed under the terms and conditions of the Creative Commons Attribution (CC BY) license (http://creativecommons.org/licenses/by/4.0/). 